\title{
Metallophthalocyanine dimers incorporating five-atom covalent bridges
}

\author{
Clifford C. Leznoff,' Sebastian M. Marcuccio, Shafrira Greenberg, and A. B. P. Lever \\ Department of Chemistry, York University. Downsview (Toronto). Ont.. Canada M3J IP3
}

AND

KENNETH B. TOMER

Midwest Center for Mass Spectrometry, University of Nebraska-Lincoln, Lincoln, NE 68588, U.S.A.

Recejved June 4, 1984

\begin{abstract}
Clifford C. Leznoff, Sebastian M. Marcuccio, Shafrira Greenberg. A. B. P. Lever. and Kenneth B. Tomer. Can. J. Chem. 63, 623 (1985).

Metal-free copper and cobalt(II) binuclear phthalocyanines, in which the two phthalocyanine nuclei are covalently linked through five-atom bridges, have been preparcd and characterized. Some new metal-free, copper, cobalt(II), and zinc 2,9,16,23tetraalkoxyphthalocyanines, some of which arc extremely soluble in organic solvents, are described.
\end{abstract}

Clifford C. Leznoff, Sebastian M. Marcuccio, Shafrira Greenberg, A. B. P. Lever et Kenneth B. Tomer. Can. J. Chem. 63, 623 (1985).

On a préparé et caractérisé une série de phtalocyanines. libres ou complexées par du cuivre ou du cobalt(II), dans lesquelles les deux noyaux de phtalocyanines sont liés d'une manière covalente par des ponts de cinq atomes. On décrit quelques nouvelles tétraalkoxy-2,9,16,23 phtalocyanines, libres ou complexées avec du cuivre, du cobalt(II) ou du zinc, qui sont extrèmement solubles dans les solvants organiques.

The use of cobalt phthalocyanine as a catalyst for the electroreduction of oxygen has been known for some time (1) and extensive research efforts have shown that porphyrins and phthalocyanines can act as potential catalysts for energy conversion processes $(2-4)$. It is well known that iron(II) porphyrins decompose oxygen through a mechanism involving two porphyrins acting on one oxygen molecule (5). Binuclear porphyrins $(6-9)$ have been prepared and used in the 4-electron reduction of molecular ox ygen to water. Under operating conditions, however, binuclear porphyrins lose catalytic activity with time (7) and it may be that the porphyrin nucleus itself is not sufficiently stable to be used as a long term photocatalyst. For this reason, we envisioned that binuclear photocatalysts based on the thermally (10) and photochemically stable phthalocyanine nucleus would be worthwhile molecules to synthesize and examine in electrochemical and photocatalytic studies.

Using a solid phase method of synthesis we have recently prepared some unsymmetrical phthalocyanines which are very soluble in organic solvents $(11,12)$, compared with most phthalocyanines which are notoriously insoluble. These soluble, unsymmetrical, mononuclear phthalocyanines contained the necessary handle, a hydroxy functional group, which could be used to attach the phthalocyanine to electrodes $(13,14)$. The synthesis of a very soluble mononuclear phthalocyanine in our earlier studies $(11,12)$ and the development of chromatographic methods for the separation of phthalocyanines in general (12) has enabled us to contemplate the syntheses of the hitherto unknown binuclear phthalocyanines.

Although we believed that a solid phase approach could be advantageously used in the synthesis of binuclear phthalocyanines, as a first experiment, prior to adopting solid phase methodology, we tried to synthesize a binuclear phthalocyanine in solution. As shown below, binuclear phthalocyanines can be separated chromatographically from mononuclear phthalocyanines using our unusual eluting solvent mixture

\footnotetext{
'Author to whom correspondence may be addressed.
}

(12), and hence the more elaborate scheme using polymer supports was unnecessary.

Synthesis of mononuclear phthalocyanines, soluble in organic solvents

Treatment of 4-nitrophthalonitrile (1) with 2-propanol (2), 2-methyl-1-propanol (3), and 2,2-dimethyl-1-propanol (4) with potassium carbonate in dimethylformamide (DMF) in a useful modification (15) of published procedures $(16,17)$ gave in some instances at high temperatures the unwanted by-products 4-hydroxyphthalonitrile (5) (18) and bis(3,4-dicyanophenyl)ether (6), but at room temperature (15) the desired 4-isopropoxyphthalonitrile (7) $(11,15)$, 4-isobutoxyphthalonitrile (8), and 4-neopentoxyphthalonitrile (9) respectively in 69 to $87 \%$ yield. Phthalonitriles 7-9 were readily converted, using gaseous ammonia and sodium methoxide in methanol $(19.20)$, to 5-isopropoxy-1,3-diiminoisoindoline (10), 5-isobutoxy-1,3diiminoisoindoline (11), and 5-neopentoxy-1,3-diiminoisoindoline (12) respectively. The solvent was evaporated and compounds 10-12 were next used without further purification. We have previously reported the condensation of 10 in 2-N,N-dimethylaminoethanol (Method $\mathrm{A}$ ) (19) to give the metal-free 2,9,16,23-tetraisopropoxyphthalocyanine (13a) (12), but had not described any metallated derivatives of $13 a$. In fact, several methods exist for the direct condensation of phthalonitriles to metallated phthalocyanines without the necessity of forming isoindolines. Thus, treatment of 7 with $\mathrm{CuCN}$ in DMF (Method B) (20) or with $\mathrm{CuCl}_{2}$ and diazabicyclononane (DBN) in ethanol (Method C) (21) gave 2,9,16,23-tetraisopropoxyphthalocyaninato copper (13b) in 34 and $49 \%$ yield respectively (Table 1). Compound 7 was similarly converted to $2,9,16,23$-tetraisopropoxyphthalocyaninato cobalt(II) (13c) and 2,9,16,23-tetraisopropoxyphthalocyaninato zinc (13d) using Methods B and C (Table 1; Scheme 1).

Isoindoline 11 was converted to the metal-free $2,9,16,23$ tetraisobutoxyphthalocyanine (14a) by Method $A$ and $14 a$ was converted to 2,9,16,23-tetraisobutoxyphthalocyaninato copper $(14 b)$ by simple treatment of $14 a$ with cupric acetate in toluene (Method D) (19), in this example (Table 1). Similarly, isoin- 


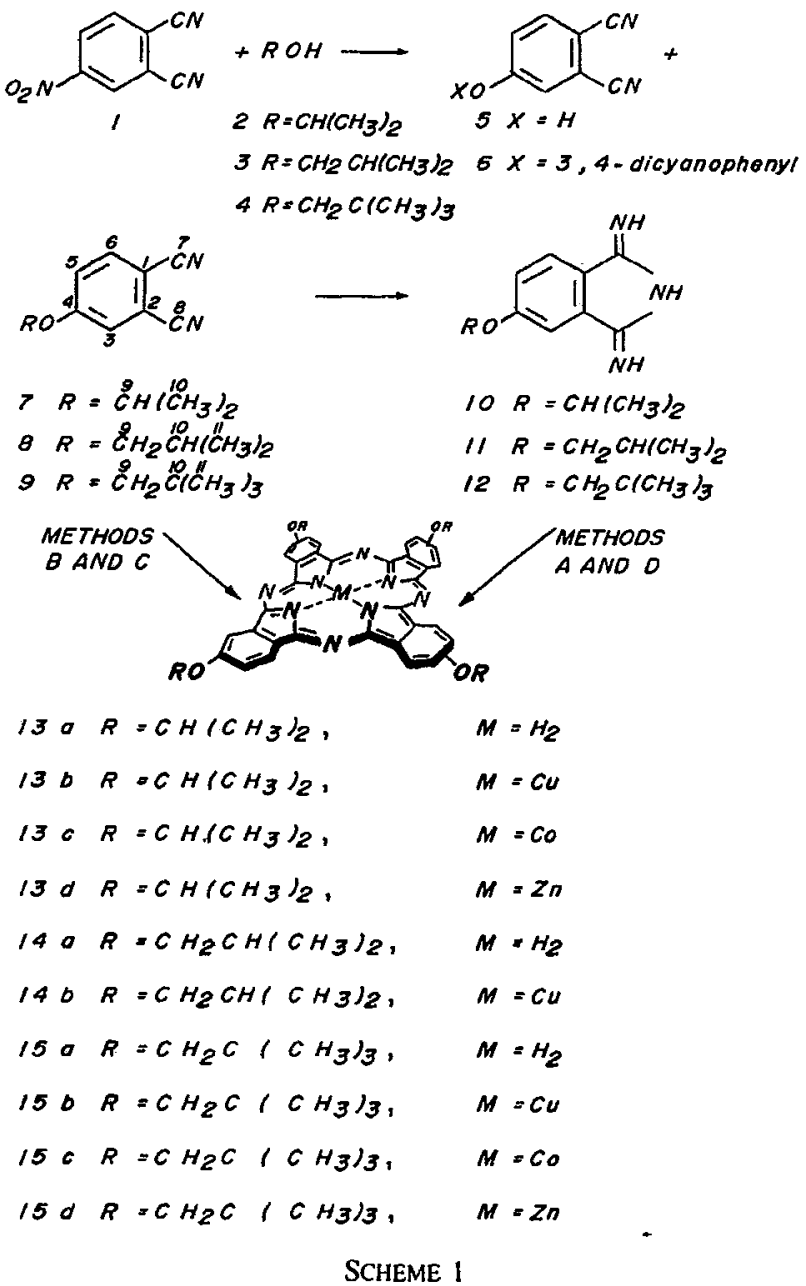

doline 12 was converted to 2,9,16,23-tetraneopentoxyphthalocyanine (15a) (Method A) and subsequently to 2,9,16,23tetraneopentoxyphthalocyaninato copper (15b) and 2,9,16,23tetraneopentoxyphthalocyaninato cobalt(II) (15c) (Method D). Treatment of phthalonitrile 9 under the conditions of Method B using copper, cobalt, and zinc salts yielded $15 b, 15 c$, and 2,9,16,23-tetraneopentoxyphthalocyaninato zinc $(15 d)$ in varying yields (Table 1; Scheme 1). The structures of $13 a-d$, $14 a-b$, and $15 a-d$ were confirmed by spectroscopic and elemental analysis (see experimental section and Table 2).

A comparison of the yields of metallophthalocyanines by three different routes (Table 1) shows that a combination of Methods $A$ and $D$, i.e. formation of metal-free phthalocyanines followed by metal insertion, or Method C, using DBN as a condensing agent, is superior to Method B. In fact, in our hands, organic soluble metallophthalocyanines are most conveniently prepared in the purest state, and in the highest yield, by metal insertion into metal-free phthalocyanines (Methods A and D). Direct preparation of metallophthalocyanines by Method $\mathrm{C}$ gives metallophthalocyanines contaminated by impurities difficult to remove by chromatographic methods.

The selection of the 4-isopropoxy group as a substituent of a phthalonitrile and hence of its isoindoline was predicated on the fact that a bulky isopropoxy group in $\mathbf{7}$ and $\mathbf{1 0}$ similar to the less accessible 4-tert-butylphthalonitrile (22) would inhibit aggregation processes and lead to organic solvent soluble phthalocyanines. Indeed, $13 a$ proved to be exceedlingly solu-
TABLE 1. Yields of monomeric metallophthalocyanines by different synthetic methods

\begin{tabular}{|c|c|c|c|c|}
\hline $\begin{array}{l}\text { Starting } \\
\text { material }\end{array}$ & Method" & Salt & Product & Yield $(\%)$ \\
\hline 7 & A & $b$ & $13 a$ & 38 \\
\hline 7 & B & $\mathrm{CuCN}$ & $13 b$ & 34 \\
\hline 7 & B & $\mathrm{CoCl}_{2}$ & $13 c$ & 20 \\
\hline 7 & B & $\mathrm{Co}(\mathrm{CN})_{2}$ & 4 & $\ldots$ \\
\hline 7 & B & $\mathrm{Co}(\mathrm{OAc})_{2}$ & $13 c$ & 37 \\
\hline 7 & B & $\mathrm{ZnCl}_{2}$ & $13 d$ & 35 \\
\hline 7 & $\mathrm{C}$ & $\mathrm{CuCl}_{2}$ & $13 b$ & 49 \\
\hline 7 & C & $\mathrm{CoCl}_{2}$ & $13 c$ & 46 \\
\hline 7 & C & $\mathrm{Co}(\mathrm{OAc})_{2}$ & $13 c$ & 35 \\
\hline 7 & $\mathrm{C}$ & $\mathrm{ZnCl}_{2}$ & $13 d$ & 31 \\
\hline 9 & A & & $15 a$ & 45 \\
\hline 9 & B & $\mathrm{CuCN}$ & $15 b$ & 17 \\
\hline 9 & B & $\mathrm{Co}(\mathrm{OAc})_{2}$ & $15 c$ & 29 \\
\hline 9 & B & $\mathrm{ZnCl}_{2}$ & $15 d$ & 2 \\
\hline 9 & B & $\mathrm{Zn}(\mathrm{OAc})_{2}$ & $15 d$ & 27 \\
\hline $14 a$ & D & $\mathrm{Cu}(\mathrm{OAc})_{2}$ & $14 b$ & 74 \\
\hline $15 a$ & D & $\mathrm{CuCl}_{2}$ & $15 b$ & $94^{d}$ \\
\hline $15 a$ & D & $\mathrm{CoCl}_{2}$ & $15 c$ & $94^{\prime \prime}$ \\
\hline
\end{tabular}

"See text for reaction conditions and references for Methods A-D.

"Method A gives metal-free phthalocyanines and no salt is used.

No reaction.

"The overall yield, which is a combination of Methods $A$ and $D$, is $42 \%$.

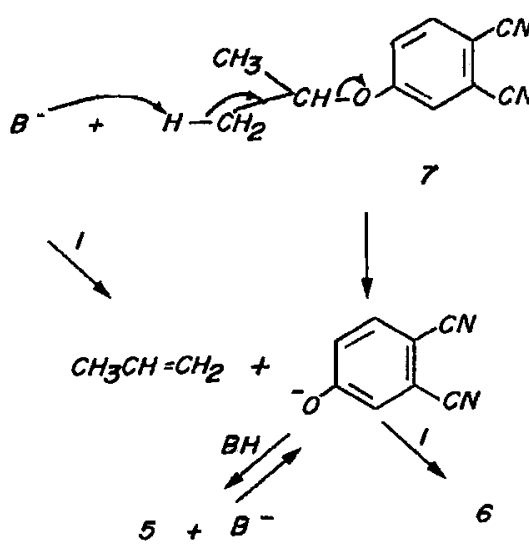

SCHEME 2

ble (Table 2) in organic solvents and hence was readily separable from polymer-supported phthalocyanines $(11,12)$ and, as shown below, separable from a binuclear phthalocyanine. Although $13 a-d$ were prepared as pure compounds, it was noted that some deterioration occurred with age and, indeed, old samples had to be rechromatographed before their use in electrochemical studies. Since the phthalocyanine nucleus is reputed to be extremely stable to decomposition, we believed for two reasons that the isopropoxy group was responsible for this instability. Firstly, isopropyl ethers are known to readily form peroxides and, secondly, base catalyzed elimination of the isopropyl group may occur as shown in Scheme 2.

The formation of 6 in the preparation of 7 at temperatures higher than room temperature shows that the mechanistic scheme shown in Scheme 2 is at least partially operative. We have shown that pure 7 on reaction with $\mathrm{K}_{2} \mathrm{CO}_{3}$ or $\mathrm{KNO}_{2}$ at $80^{\circ} \mathrm{C}$ does liberate, upon protonation, 5 without concomitant formation of $\mathbf{6}$, since no $\mathbf{1}$ is available. Some earlier studies (23) on the formation of tert-butyl aryl ethers have shown that 
TABLE 2. Absorption spectra of mononuclear and binuclear phthalocyanines and their solubilities in $\mathrm{CH}_{2} \mathrm{Cl}_{2}$ at $24^{\circ} \mathrm{C}$

\begin{tabular}{|c|c|c|c|c|c|c|c|}
\hline \multirow{2}{*}{$\frac{\text { Phthalocyanine }}{13 a}$} & \multicolumn{6}{|c|}{$\lambda \max (n m)(\epsilon \log )$} & \multirow{2}{*}{$\frac{\begin{array}{c}\text { Solubility } \\
(\mathrm{mol} / \mathrm{L})\end{array}}{0.78}$} \\
\hline & $342(4.40)$ & $388(4.09)$ & $608(3.98)$ & $640(4.19)$ & $670(4.58)$ & $706(4.64)$ & \\
\hline $13 b$ & $338(4.74)$ & $384(4.37)$ & $614(4.47)$ & $638(4.48)$ & $677(4.93)$ & & 0.62 \\
\hline $13 c$ & $328(4.72)$ & $386(4.32)$ & $608(4.40)$ & , & $674(4.92)$ & & 0.84 \\
\hline $13 d$ & $342(4.67)$ & $384(4.26)$ & $614(4.32)$ & & $682(4.96)$ & & 0.30 \\
\hline $14 a$ & $343(4.98)$ & $390(4.54)$ & $610(4.47)$ & $642(4.66)$ & $670(4.97)$ & $706(5.02)$ & 0.013 \\
\hline $14 b$ & $337(4.76)$ & $384(4.40)$ & $620(4.59)$ & & $682(4.89)$ & & 0.018 \\
\hline $15 a$ & $34 !(4.57)$ & $390(4.27)$ & $608(4.17)$ & $642(4.36)$ & $670(4.73)$ & $705(4.79)$ & 1.10 \\
\hline $15 b$ & $338(4.82)$ & $380(4.42)$ & $614(4.57)$ & & $680(5.09)$ & & 0.26 \\
\hline $15 c$ & $335(4.74)$ & $390(4.31)$ & $620(4.52)$ & & $680(4.97)$ & & 0.15 \\
\hline $15 d$ & $344(4.91)$ & $384(4.57)$ & $614(4.60)$ & & $680(5.18)$ & & 0.43 \\
\hline 25 & & $384(4.10)$ & $618(4.57)$ & & $682(4.99)$ & & - \\
\hline $26 a$ & $336(4.99)$ & $384(4.69)$ & $612(4.80)$ & $636(4.90)$ & $668(4.84)$ & $700(4.69)$ & 0.0057 \\
\hline $26 b$ & $336(5.08)$ & $384(4.72)$ & & $628(5.06)$ & $676(5.03)$ & & 0.00028 \\
\hline $26 c$ & $320(4.95)$ & $386(4.56)$ & & $626(4.92)$ & $670(4.88)$ & & $0.0007 !$ \\
\hline $27 a$ & $332(5.00)$ & $384(4.66)$ & $610(4.76)$ & $638(4.90)$ & $670(4.81)$ & $700(4.66)$ & 0.35 \\
\hline $27 b$ & $320(4.95)$ & $380(4.37)$ & & $626(4.77)$ & $668(4.76)$ & & 0.039 \\
\hline
\end{tabular}

eliminative processes as described above do occur but also that elimination more likely occurs through an alternate pathway involving the initial nucleophilic addition adduct. In any case, it became apparent that the 4-isopropoxy group of 7 and $\mathbf{1 0}$ was not ideally suited to subsequent use as a "partner" in the synthesis of binuclear phthalocyanines. It was for these reasons that the isobutoxy derivatives 8 and 11 were prepared. The isobutoxy group is not a secondary ether and hence is less susceptible to peroxide formation, and in addition only contains one hindered $\beta$-hydrogen for participation in possible elimination reactions. It was subsequently shown, however, that the isobutoxyphthalocyanines, $14 a$ and $14 b$, prepared from 11, were considerably less soluble than their isopropoxy analogs, $13 a$ and $13 b$ (Table 2). The 4-neopentoxy derivatives, 9 and 12, are primary hindered ethers and contain no $\beta$-hydrogens for possible elimination reactions. Most importantly, the neopentoxyphthalocyanine, $15 a$, derived from 12 , proved to be exceedingly soluble in organic solvents (Table 2) and ultimately exhibited little decomposition with age. The formation of 9 at room temperature using the standard procedure (15) gave 9 in $86 \%$ yield in $84 \mathrm{~h}$ in a small scale reaction. On a large scale, the reaction was only completed after $144 \mathrm{~h}$. Since 9 could not undergo $\beta$-elimination processes such as 7, an evaluation of the yield of 9 at different temperatures was undertaken and it was shown that 9 should be prepared in optimal yield in reasonable times at $60^{\circ} \mathrm{C}$ (Table 3). At higher temperatures, the formation of 5 by the displacement of the nitro group by carbonate or nitrite becomes important (18).

\section{The syntheses of binuclear phthalocyanines}

A straightforward route to binuclear phthalocyanines would involve a mixed condensation of a bisphthalonitrile or its isoindoline derivatives with a simple phthalonitrile or isoindoline in solution. Since phthalocyanines are so insoluble, the above simple approach would give insoluble, inseparable mixtures of mononuclear phthalocyanines, binuclear phthalocyanines, and by-products, as even good preparations of mononuclear phthalocyanines occur in less than $50 \%$ yield. The development $(11,12)$ of exceedingly soluble mononuclear phthalocyanines and particularly $15 a$ described above indicated that even binuclear phthalocyanines may be soluble and separable
TABle 3. Yields of 9 from 1 at different temperatures and reaction times

\begin{tabular}{ccc}
\hline \hline Temperature $\left({ }^{\circ} \mathrm{C}\right)$ & Time $(\mathrm{h})^{\prime \prime}$ & Yield (\%) \\
\hline 22 & 84 & 86 \\
60 & 18 & 82 \\
70 & 10 & 76 \\
80 & 5 & 66 \\
\hline
\end{tabular}

"Starting material 1 was completely consumed after the given reaction times.

by chromatography (12).

Initially, we had been interested in preparing not only binuclear phthalocyanines but also one containing a "handle" suitable for attachment to electrodes (13), polymers (24), or micelles (25). In addition, we wished to prepare binuclear phthalocyanines, incorporating five-, four-, or three-atom covalent bridges, as these bridges seemed most likely to yield phthalocyanine dimers having electrocatalytic and photocatalytic activity. Bisphthalonitriles can be readily prepared (16) by treatment of symmetrical diols with 1 . The goal of obtaining binuclear phthalocyanines incorporating a five-atom bridge thus requires a bisphthalonitrile incorporating a fiveatom bridge. The symmetrical diol forming this bridge should not have hydrogen atoms available for $\beta$-elimination. Treatment of excess 2-hydroxymethyl-2-methyl-1,3-propanediol (16) with triphenylmethyl chloride (trityl chloride) in pyridine yielded upon column chromatography $68 \%$ (based on trityl chloride) of 2-methyl-2-trityloxymethyl-1,3-propanediol (17).

Symmetrical diols 17, 2,2-dimethyl-1,3-propanediol (18), and 2-ethyl-2-methyl-1,3-propanediol (19), reacted with more than two equivalents of 1 and $\mathrm{K}_{2} \mathrm{CO}_{3}$ in dimethylsulfoxide (DMSO) (16) to give I 3-bis ( $3^{\prime}, 4^{\prime}$-dicyanophenoxy)-2-methyl2-trityloxymethylpropane (20), 1,3-bis ( $3^{\prime}, 4^{\prime}$-dicyanophenoxy)2,2-dimethylpropane (21), and I,3-bis $\left(3^{\prime}, 4^{\prime}\right.$-dicyanophenoxy)2-ethyl-2-methylpropane (22) respectively. Bisnitriles 21 and 22 were converted to their bisisoindolines 23 and 24 as before and used in subsequent condensations without further purification. For our first mixed condensation for the preparation of binuclear phthalocyanines we decided to try the direct route of reacting bisphthalonitrile 20 with 4 -isopropoxyphthalonitrile 
(7) using cuprous cyanide in DMF (Method B), as Method C was known to generate many by-products. Flash chromatography (26) using 2-methoxyethanol - toluene $(5: 200)$ as eluant removed the mononuclear copper phthalocyanine $13 b$, formed by self-condensation of 7 . Further elution gave the binuclear phthalocyanine, 1,3-bis- $2^{\prime}-\left(9^{\prime}, 16^{\prime}, 23^{\prime}\right.$-triisopropoxyphthalocyaninato copper)-2-methyl-2-trityloxymethylpropane (25), in 1\% yield (Scheme 3 ). Characterization of 25 was based on elemental and spectroscopic analysis and its method of synthesis. Elemental analysis of 25, which still contains the trityl blocking group, is more meaningful than elemental analysis of any detritylated dimer, as $\mathbf{2 5}$ exhibits a more considerable difference in its calculated analysis than the related monomer $13 b$. Indeed, the close but not perfect analysis indicates the structure 25 , rather than a monomeric species. The mass spectrum of $\mathbf{2 5}$ was most informative and, after much effort using the FAB techniques (27) and using thioglycerol as solvent, a parent ion with $\mathrm{m} / \mathrm{z}$ centered at $1859.5 \mathrm{amu}$ was observed. A major fragment ion at $1816\left(M^{+}-43\right)$ was indicative of loss of an isopropyl group, consistent with structure 25 . The much slower chromatographic mobility of 25 compared to $13 b$ further suggested 25 as the most likely structure. The infrared spectrum of $\mathbf{2 5}$ gives us an indication of the purity of our compounds, as by-product impurities exhibit absorptions in the nitrile or carbonyl regions of the spectra which are absent in both pure mononuclear and binuclear phthalocyanines. The ultraviolet spectrum of $\mathbf{2 5}$ and all mononuclear and binuclear phthalocyanines are given in Table 2 for comparison purposes, as small but significant differences are apparent between metalfree and metallophthalocyanines and between mononuclear and binuclear phthalocyanines.

Although the synthesis of the first binuclear phthalocyanine 25 was achieved using Method B and 7 as the "partner" in the condensation, the yield was very low. For this" reason the formation of binuclear phthalocyanines using Method A (via diiminoisoindolines) and using 5-neopentoxy-1,3-diiminoisoindoline (12) as the "partner" was attempted. Heating the bisisoindolines 23 or 24 at $150^{\circ} \mathrm{C}$ with a large excess of 12 in 2- $N, N$-dimethylaminoethanol for $24 \mathrm{~h}$ (Method $\mathrm{A}$ ) under argon yielded a dark blue solution which was diluted with water giving blue coloured residues. Flash chromatography of solutions of these residues separated the mononuclear phthalocyanine $15 a$ from the desired binuclear phthalocyanines 1,3bis-2'-(9',16',23'-trineopentoxyphthalocyaninoxy)-2,2-dimethylpropane (26a) and 1,3-bis- $2^{\prime}-\left(9^{\prime}, 16^{\prime}, 23^{\prime}\right.$-trineopentoxy phthalocyaninoxy)-2-ethyl-2-methylpropane (27a) respectively. The relatively high yields of $26 a(17 \%)$ and $27 a(10 \%)$ achieved by Method A as compared to Method B for 25 (1\%) more than compensated for the extra effort of making the isoindolines. Simple treatment of $26 a$ with anhydrous cupric acetate in toluene at $100^{\circ} \mathrm{C}$ for $17 \mathrm{~h}$ gave the binuclear phthalocyaninato dicopper derivative $26 b$ in $54 \%$ yield, while similar reactions of $26 a$ or $27 a$ with anhydrous cobaltous chloride gave the binuclear phthalocyaninato dicobalt(II) derivatives $26 \mathrm{c}$ and $27 b$ in 60 and $74 \%$ yields respectively. Binuclear phthalocyanines, $26 a-c$ and $27 a-b$, exhibited parent ions in their mass spectra using the FAB system and $a$-nitrophenyl octyl ether (ONPOE) as solvent. The infrared spectra of $26 a$ and $27 a$ exhibit characteristic $\mathrm{N}-\mathrm{H}$ absorptions at 3300 and $1020 \mathrm{~cm}^{-1}$ (28), similar to metal-free mononuclear phthalocyanines $13 a$, $14 a$, and $15 a$. The ${ }^{1} \mathrm{H}$ nmr spectra of $26 a$ and $27 a$ show a characteristic broad $\mathrm{N}-\mathrm{H}$ absorption peak at approximately $-6.0 \mathrm{ppm}$ as do $13 a, 14 a$, and $15 a$ at high concentrations.
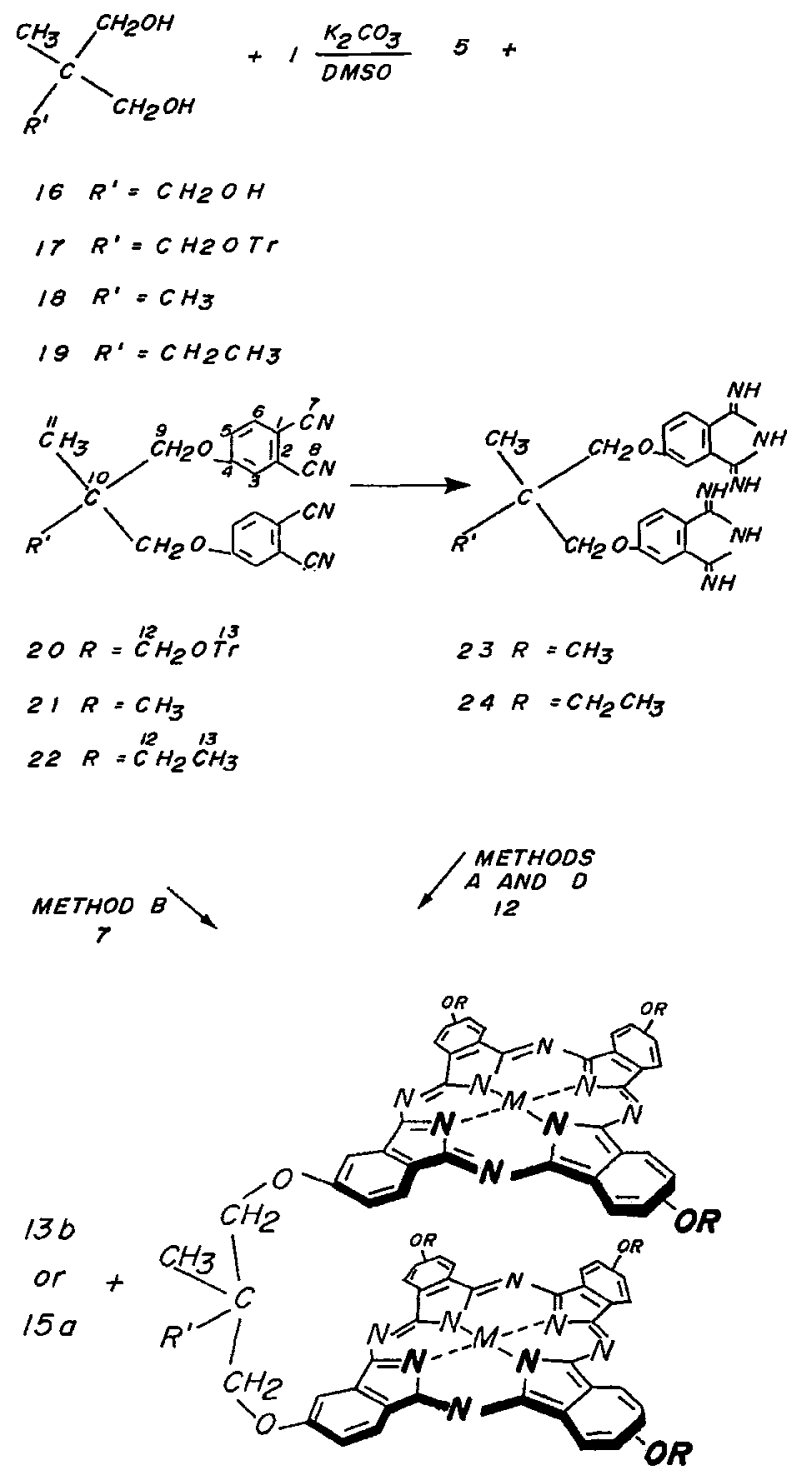

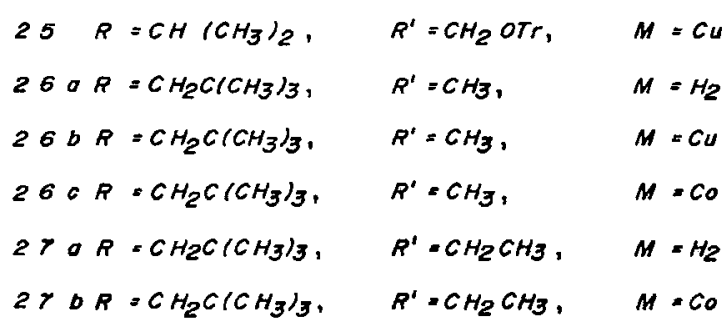

SCHEME 3

Other peaks in the ' $\mathrm{H}$ nmr spectra, however, are also very broad, which renders ' $\mathrm{H}$ nmr spectroscopy less useful for characterization of phthalocyanines, both monomeric and dimeric. It is likely that the ' $\mathrm{H}$ nmr signals are broad due to both aggregation effects and the fact that all the mononuclear and binuclear phthalocyanines described herein are a mixture of a large number of possible positional isomers. Even using a high field instrument and multiple scans, a dilute solution of $15 a$ yielded a spectrum showing broad absorptions, and hence the multiplicity of positional isomers is the likely primary cause of this effect. The ${ }^{13} \mathrm{C} \mathrm{nmr}$ spectra (see Experimental), of $13 a$, 
TABLE 4. "'C Chemical shifts of 7-9 and 20-22

\begin{tabular}{|c|c|c|c|c|c|c|}
\hline \multirow[b]{2}{*}{ Carbon" } & \multicolumn{6}{|c|}{$\delta \mathrm{ppm}$} \\
\hline & 7 & 8 & 9 & 20 & 21 & 22 \\
\hline I & 106.3 & 106.1 & 106.7 & 107.1 & 107.7 & 107.4 \\
\hline 2 & 117.1 & 116.5 & 117.2 & 117.0 & 117.6 & 117.4 \\
\hline 3 & $119.9^{\prime \prime}$ & 119.2 & $119.5^{\prime \prime}$ & $119.2^{11}$ & $119.8^{\prime \prime}$ & $119.5^{\prime}$ \\
\hline 4 & 161.1 & 161.9 & 162.6 & 161.5 & 162.4 & 162.0 \\
\hline 5 & $120.3^{\prime \prime}$ & 119.2 & $119.8^{\prime \prime}$ & $119.5^{b}$ & $120.0^{\prime \prime}$ & $119.7^{\prime}$ \\
\hline 6 & 135.1 & 135.1 & 135.3 & 135.1 & 135.6 & 135.3 \\
\hline 7 & $115.3^{\circ}$ & $115.1^{\circ}$ & 115.9 & $115.1^{\circ}$ & $115.7^{\circ}$ & $115.2^{\circ}$ \\
\hline 8 & $115.7^{\circ}$ & $115.6^{\circ}$ & 115.9 & $115.5^{\circ}$ & $116.1^{\circ}$ & $115.7^{\circ}$ \\
\hline 9 & 71.6 & 75.0 & 78.9 & 70.5 & 74.1 & 72.0 \\
\hline 10 & $21.5^{\prime}$ & 27.6 & 31.9 & 40.4 & 36.1 & 38.3 \\
\hline 11 & - & 18.5 & 26.4 & 17.3 & 21.8 & 18.3 \\
\hline 12 & - & - & - & 63.5 & - & 26.6 \\
\hline 13 & - & - & - & $86.4^{\circ}$ & - & 7.3 \\
\hline
\end{tabular}

"The numbering of the carbon atoms in 7-9 and 20-22 follows that given for these structures in Schemes 1 and 2 and does not follow from the names of these compounds. All compounds were run in $\mathrm{CDCl}_{3}$ except 21. which was run in $\mathrm{CD}_{2} \mathrm{Cl}_{2}$.

"These assignments may be interchanged.

"These assignments may be interchanged.

"This value is typical of methyl carbon atoms and correlates well with carbon II for other compounds in the tabie.

"This assignment is for the quaternary carbon of the trityl group. The phenyl groups absorb at 143.3, 128.4, 127.7, and 127.0, consistent with previous assignments (30).

$13 d, 14 a, 15 a, 15 d, 26 a$, and $27 a$ give sharp absorbancies, characteristic of the given structures. The reduced solubilities of $26 a$ and $27 a$ compared to $13 a$ and $15 a$ meant that even overnight scans of these samples on a Bruker $400-\mathrm{MHz} \mathrm{nmr}$ spectrometer could not show most of the quaternary carbon atoms. The ${ }^{13} \mathrm{C}$ nmr of 7-9 and 20-22 have been assigned using standard correlations (29) (Table 4). The absorption spectra of all mononuclear and binuclear phthalocyanines reported herein are reported in Table 2 . Mononuclear metal-free and metallophthalocyanines give well-known characteristic absorption spectra (10) and the present availability of binuclear metal-free and metallophthalocyanines shows that these dimeric phthalocyanines are different from the monomeric phthalocyanines and from each other. Both mononuclear and binuclear metal-free phthalocyanines exhibit absorption maxima between 700 and $706 \mathrm{~nm}$ with the binuclear ones absorbing near $700 \mathrm{~nm}$. Metallophthalocyanines do not give absorption maxima at this wavelength. Other differences, especially between monomers and dimers, are reflected in intensity changes which in tabular form appear minor, but in graphic form (Fig. 1) of one example of each class show that simple inspection can often identify the phthalocyanine as mononuclear or binuclear, and metal-free or containing metal.

The successful syntheses of the first characterized binuclear phthalocyanines rest largely on the preparation of monomeric phthalocyanines, which are exceedingly soluble in organic solvents, and their subsequent separation from binuclear phthalocyanines which still exhibit significant solubility in organic solvents. From Table 2 one can see that metallophthalocyanines are generally less soluble than metal-free phthalocyanines, and binuclear phthalocyanines are understandably less soluble than mononuclear phthalocyanines. Thus the difference in solubility of metal-free mononuclear phthalocyanine (15a) and a binuclear metallophthalocyanine $(26 c)$ is over three orders of magnitude, but $26 c$ and other

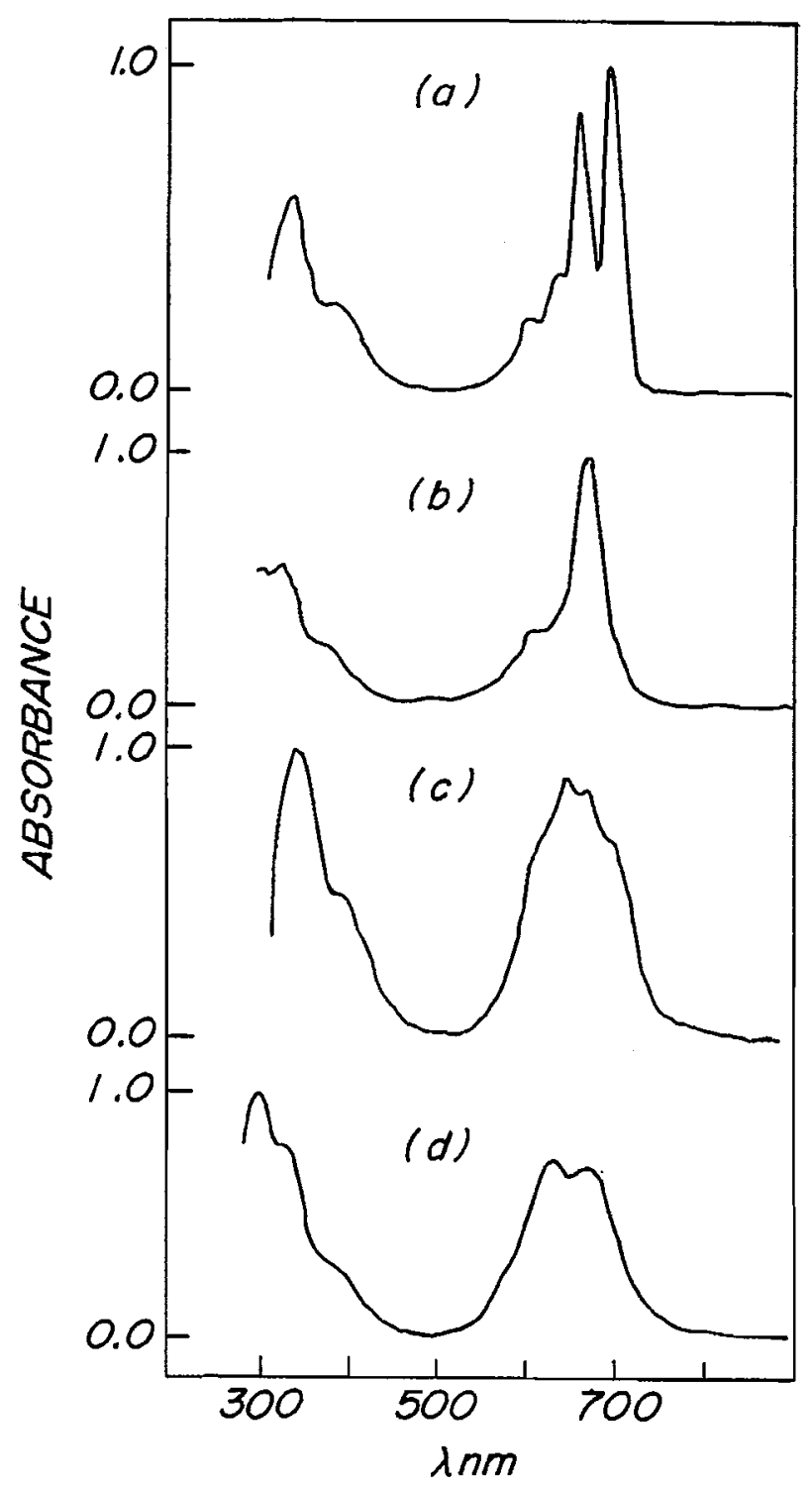

FIG. 1. The $\lambda(\mathrm{nm})$ visible spectra in $\mathrm{CH}_{2} \mathrm{Cl}_{3}$ at room temperature of (a) a mononuclear metal-free phthalocyanine, $13 a$, (b) a mononuclear metallophthalocyanine, $13 c$, (c) a binuclear metal-free phthalocyanine, 27a. (d) a binuclear metallophthalocyanine, $27 b$.

phthalocyanine dimers are still sufficiently soluble to purify and characterize. A full analysis of $26 a-c$ and $27 a-b$ by visible spectroscopy and electrochemical methods under a variety of conditions has been undertaken and a preliminary report has appeared (31).

\section{Experimental}

Matheson high purity argon was used to maintain inert atmosphere coniditions. Infrared (ir) spectra were recorded on a Pye Unicam SP1000 infrared spectrophotometer using $\mathrm{KBr}$ discs for solids or as neat films between $\mathrm{NaCl}$ discs. Nuclear magnetic resonance (nmr) spectra for protons were recorded on a Varian LM 360 spectrometer using deuterochloroform as solvent and tetramethylsilane as the internal standard. The positions of the signals are reported in $\delta$ units. (The splittings of the signals are described as singlets (s), doublets (d), triplets $(t)$, quartets $(q)$, or multiplets $(m)$.) A Bruker WH250 or WH400 spectrometer was used for all ${ }^{1.3} \mathrm{C} \mathrm{nmr} \mathrm{spectra}$ and for ${ }^{\prime} \mathrm{H} \mathrm{nmr}$ spectra of $13 a, 13 d, 14 a, 15 a, 15 d, 26 a$, and $27 a$ at $10^{-2}$ to $10^{-1} M$. 
The visible-ultraviolet spectra (uv) were recorded on a PerkinElmer-Hitachi 340 spectrometer. Mass spectra (ms) were recorded at $70 \mathrm{eV}$ on a VG Micromass $16 \mathrm{~F}$ mass spectrometer in the $\mathrm{El}$ mode.

The FAB spectra were obtaincd with a Kratos MS-50 triple analyzer mass spectrometer equipped with a FAB ion source of standard Kratos design and an lon Tech atom gun. The sample was dissolved in chloroform and a microliter of the resulting solution added to a microliter of o-nitrophenyloctylether on the probe tip. The spectra of the molecular ions of the binuclear phthalocyanines were obtained by signal averaging up to 256 scans over the appropriate mass range. The number in parentheses after the indicated ion shows the percentage of the base peak represented by that ion. Melting points (mp) were determined using a Kofler hot stage melting point apparatus and are uncorrected. Thin-layer chromatography (tlc) was performed using silica gel $G$ as the adsorbent. All reactions were stirred with a magnetic stirrer. All solvents were freshly distilled before use. Microanalyses were performed by Guelph Chemical Laboratories Ltd., Guelph, Ont.

\section{Bis-(3,4-dicyanophenyl)ether (6) and 4-isopropoxyphthalonitrile (7)}

\section{At room temperature}

In a minor modification of Siegl's procedure (15) 4-nitrophthalonitrile $(1.64 \mathrm{~g}, 9.49 \mathrm{mmol})$, isopropanol $(2.0 \mathrm{~mL}, 26 \mathrm{mmol})$, and anhydrous potassium carbonate $(2.94 \mathrm{~g}, 21.3 \mathrm{mmol})$ were stirred at room temperature under an argon atmosphere in $10 \mathrm{~mL}$ of dry DMF for $43 \mathrm{~h}$. The potassium carbonate was added in three portions. The crude reaction mixture was poured into water $(300 \mathrm{~mL})$. The precipitate was collected by filtration, washed thoroughly with water, and dried. The crude product was purified by silica gel column chromatography using ether - petroleum ether $(2: 3)$ as the eluting solvent. It was then recrystallized from a mixture of ether-hexanes to give $1.21 \mathrm{~g}$ of slightly yellow crystals of 4-isopropoxyphthalonitrile (7), $\mathrm{mp} 58-59^{\circ} \mathrm{C}$ (lit. $(11,15) \mathrm{mp} 56-57^{\circ} \mathrm{C}$ ) in $69 \%$ yield.

\section{At $50-60^{\circ} \mathrm{C}$}

In another experiment, $17.3 \mathrm{~g}$ of 4 -nitrophthalonitrile $(0.10 \mathrm{~mol})$ reacted with $24 \mathrm{~mL}$ of isopropanol $(0.31 \mathrm{~mol})$ and $32 \mathrm{~g}$ of anhydrous potassium carbonate $(0.23 \mathrm{~mol})$ in $120 \mathrm{~mL}$ of dry DMF and the mixture was heated at $50-60^{\circ} \mathrm{C}$ under Ar for $93 \mathrm{~h}$. Under these conditions and using an identical work-up as before, a mixture of bis(3,4-dicyanophenyl)ether (6) (15) and (7) was obtained. Compound 7 was separated from the insoluble 6 by extraction with ether. The 4-isopropoxyphthalonitrile (7) was further purified by column chromatography, followed by recrystallization as before to yield 6.10 $g$ of $(7)$ in $33 \%$ yield.

Further purification of 6 by recrystallization from acetonitrile gave in $44 \%$ yield $6.0 \mathrm{~g}$ of $6, \mathrm{mp} 256-257^{\circ} \mathrm{C}$ (lit. (15) $\mathrm{mp} 254-256^{\circ} \mathrm{C}$ ).

\section{4-Isobutoxyphthalonitrile (8)}

Treatment of $5.19 \mathrm{~g}(30 \mathrm{mmol})$ of 1 with $4.44 \mathrm{~g}(60 \mathrm{mmol})$ of isobutyl alcohol (3) in DMF for $240 \mathrm{~h}$ at room temperature as described above for the preparation of 7 yielded after distillation in a Kugelrohr apparatus $5.3 \mathrm{~g}$ of 4-isobutoxyphthalonitrile (8) in $87 \%$ yield. Thin-layer chromatography of the crude reaction mixture indicated the presence of a small amount of 4-hydroxyphthalonitrile (5) (18) but this product was not isolated. Crystallization of a small sample of 8 from ethyl acetate - petroleum ether gave colourless crystals of 8, $\mathrm{mp} 49-49.5^{\circ} \mathrm{C}$; ir $\left(\mathrm{cm}^{-1}\right): 2240(\mathrm{CN}), 1600(\mathrm{C}=\mathrm{C})$, $1562(\mathrm{C}=\mathrm{C}) ;{ }^{1} \mathrm{H} \mathrm{nmr}\left(\mathrm{CDCl}_{3}\right) \delta: 7.9-7.2(\mathrm{~m}, 3 \mathrm{H}$, aromatic $), 3.9(\mathrm{~d}$, $\left.2 \mathrm{H}, \mathrm{CH}_{2} \mathrm{O}, J=6 \mathrm{~Hz}\right), 2.2(\mathrm{~m}, 1 \mathrm{H}, \mathrm{CH}), \mathrm{I} .1\left(\mathrm{~d}, 6 \mathrm{H},\left(\mathrm{CH}_{3}\right)_{2} \mathrm{C}, J=\right.$ $6.0 \mathrm{~Hz}) ; \mathrm{ms}, m / z: 200\left(\mathrm{M}^{+}, 29\right), 142(42), 144(40), \mathrm{l}^{\prime} 27(21), 57$ (100), $56(70), 55(21), 43(24), 41$ (43), 39 (56). Anal. calcd. for $\mathrm{C}_{12} \mathrm{H}_{12} \mathrm{~N}_{2} \mathrm{O}$ : C 71.98, H 6.04, N 13.99; found: C 72.08, H 5.84, N 13.98 .

\section{4-Neopentoxyphthalonitrile (9)}

A solution of $1.73 \mathrm{~g} \mathrm{(10} \mathrm{mmol)} \mathrm{of} 1,2.30 \mathrm{~g} \mathrm{(26} \mathrm{mmol)} \mathrm{of} \mathrm{neopentyl}$

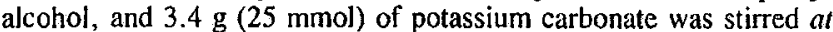
$60^{\circ} \mathrm{C}$ (Table 3) as described for the preparation of 7 above. Column chromatography of the reaction product on silica using ethyl acetate petroleum ether $(1: 19)$ gave in $82 \%$ yield $1.60 \mathrm{~g}$ of 4-neopentoxy- phthalonitrile (9), mp $61.5-62^{\circ} \mathrm{C}$; ir $\left(\mathrm{cm}^{-1}\right): 2230(\mathrm{CN}), 1590$ $(\mathrm{C}=\mathrm{C}), 1562(\mathrm{C}=\mathrm{C})$; ' $\mathrm{H} \mathrm{nmr}\left(\mathrm{CDCl}_{3}\right) 8: 7.9-7.2(\mathrm{~m}, 3 \mathrm{H}$, aromatic), $3.75\left(\mathrm{~s}, 2 \mathrm{H}, \mathrm{CH}_{2} \mathrm{O}\right), \mathrm{l} .05\left(\mathrm{~s}, 9 \mathrm{H}, \mathrm{CH}_{3} \mathrm{C}\right) ; \mathrm{ms}, \mathrm{m} / \mathrm{z}: 214\left(\mathrm{M}^{+}\right.$, 9), 199 (16), $157(2), 145(3), 72(7), 71(91), 70(14), 57(31), 55$ (22), 43 (100), $4 \mathrm{I}$ (11). Anal calcd. for $\mathrm{C}_{13.3} \mathrm{H}_{14} \mathrm{~N}_{2} \mathrm{O}$ : C 72.87, $\mathrm{H} 6.58$, N 13.07; found: C 72.89, H 6.66, N 12.89 .

Thin-layer chromatography of the crude reaction product indicated the presence of a small amount of $5(18)$ but this product was not isolated.

Preparation of 5-isopropoxy-1,3-diiminoisoindoline (10), 5-isobutoxy-I,3-diiminoisoindoline (11), and 5-neopentoxy-I,3diiminoisoindoline (12)

All diiminoisoindolines were prepared as previously described (19). In a typical example $246 \mathrm{mg}(1.15 \mathrm{mmol})$ of 9 was converted to 297 $\mathrm{mg}$ of 12 which was used directly in condensation reactions without further purification. Compounds 10-12 did not exhibit nitrile absorptions in their ir spectra.

Preparation of 2,9,16,23-tetraisopropoxyphthalocyanine (13a), $2,9,16,23$-tetraisobutoxyphthalocyanine $(14 \mathrm{a})$, and 2,9,16,23tetraneopentoxyphthalocyanine (15a) (Method A)

Compound $13 a$ was previously prepared in our laboratory $(11,12)$ from 10 using the procedure of Beach et al. (19) and purified by column chromatography using ether - petroleum ether as eluant.

A solution of 11 derived from $600 \mathrm{mg}$ of 8 in 2-N,N-dimethylaminoethanol underwent self-condensation as for the preparation of $13 a$ to give $285 \mathrm{mg}$ of a crude reaction product. Flash chromatography (26) of this product using 2-methoxyethanol - toluene $(1: 40)$ as eluant gave upon evaporation of the solvent a purer product, still containing a trace of fluorescent material on examination by tlc. Further purification by flash chromatography yielded upon evaporation of the solvent $163 \mathrm{mg}$ of very pure 2,9,16,23-tetraisobutoxyphthalocyanine $(14 a)$ as a shiny blue solid in $27 \%$ yield; ir $\left(\mathrm{cm}^{-1}\right): 3300$ $(\mathrm{NH}), 1630(\mathrm{C}=\mathrm{C}), 1245,1100,1015(\mathrm{NH}), 750$; ' $\mathrm{H} \mathrm{nmr}\left(\mathrm{CD}_{2} \mathrm{Cl}_{2}\right.$, $400 \mathrm{MHz}) 8: 7.5-6.6\left(\mathrm{~m}, 12 \mathrm{H}\right.$, aromatic), 3.7 (br s, $\left.8 \mathrm{H}, \mathrm{CH}_{2} \mathrm{O}\right), 2.2$ $(\mathrm{m}, 4 \mathrm{H}, \mathrm{CH}), \mathrm{l} .2$ (br s, 24H, $\left.\mathrm{CH}_{3}\right),-5.8$ (very br s, $\left.2 \mathrm{H}\right) ;{ }^{13} \mathrm{C} \mathrm{nmr}$ $\left(\mathrm{CD}_{2} \mathrm{Cl}_{2}, 400 \mathrm{MHz}\right) 8: 159.9$ (aromatic $\mathrm{C}-\mathrm{O}$ ), 121.9, 121.7, 117.2, 103.6, $74.5\left(\mathrm{CH}_{2}-\mathrm{O}\right), 28.6\left(\mathrm{CHCH}_{2}\right), 19.3\left(\mathrm{CH}_{3}\right) ; \mathrm{ms} \mathrm{m} / \mathrm{z}: 804$ $\left(\mathrm{M}^{+}, 54\right), 803(100), 802(82), 746(17)$. Anal. calcd. for $\mathrm{C}_{48} \mathrm{H}_{50} \mathrm{~N}_{4} \mathrm{O}_{4}$ : C 71.79, H 6.29, N 13.95; found: C 72.02, H 5.84, N 13.98 .

Similarly, the isoindoline 12 , derived from $246 \mathrm{mg}$ of phthalonitrile 9, yielded on condensation a crude product. Flash chromatography using freshly distilled toluene as eluant gave upon evaporation of the solvent $112 \mathrm{mg}$ of a dark blue, shining solid in $45 \%$ yield; ir $\left(\mathrm{cm}^{-1}\right)$ : $3290(\mathrm{NH}), 1620(\mathrm{C}=\mathrm{C}), 1240,1100,1060,1015(\mathrm{NH}), 750 ;{ }^{1} \mathrm{H}$ nmr $\left(\mathrm{CD}_{2} \mathrm{Cl}_{2}, 250 \mathrm{MHz}\right) \delta: 7.6-6.0(\mathrm{~m}, 12 \mathrm{H}$, aromatic $), 3.8(\mathrm{~s}, 8 \mathrm{H}$, $\left.\mathrm{CH}_{2} \mathrm{O}\right), 1.5\left(\mathrm{~s}, 36 \mathrm{H}, \mathrm{CH}_{3}\right),-6.5(\mathrm{br}, 2 \mathrm{H}, \mathrm{N} H) ;{ }^{13} \mathrm{C} \mathrm{nmr}\left(\mathrm{CD}_{2} \mathrm{Cl}_{2}\right.$, $250 \mathrm{MHz}$ ) $\delta: 160.6$ (aromatic $\mathrm{C}-\mathrm{O}$ ), $122.1,117.4,117.2,78.6$ $\left(\mathrm{CH}_{2}-\mathrm{O}\right), 78.4\left(\mathrm{CH}_{2} \mathrm{O}\right), 32.5\left(\mathrm{CH}_{3} \mathrm{C}\right), 27.3\left(\mathrm{CH}_{3} \mathrm{C}\right) ; \mathrm{ms}, \mathrm{m} / \mathrm{z}: 859$ $\left(\mathrm{M}^{+}, 100\right), 858(62), 801$ (2), 789 (23). Anal. calcd. for $\mathrm{C}_{52} \mathrm{H}_{5 x} \mathrm{~N}_{8} \mathrm{O}_{4}$ : C 72.70, H 6.80, N 13.04; found: C 72.78, H 6.86, N 13.00 .

General procedures for the preparation of mononuclear metallophthalocyanines (Methods $B$ and $C$ )

Mononuclear metallophthalocyanines were prepared in varying yields (Table 1) according to the procedures of Pawlowski and Hanack (20) (Mcthod B) and Tomoda et al. (21) (Method C) from the corresponding phthalonitriles. The metallophthalocyanines were isolated from the reaction mixture by dilution with water, filtration, and thorough washing with water, except for the case in which cuprous cyanide was used as the salt, in which the reaction mixture was treated with aqueous ammonia prior to washing with water. The metallophthalocyanines were purified by flash chromatography (26) using 2-methoxyethanol - toluene 1:40 as the eluting solvent.

\section{2,9,16,23-Tetraisopropoxyphthalocyaninatocopper (13b)}

In a typical procedure (Method B) (20), $0.21 \mathrm{~g}(1.15 \mathrm{mmol})$ of 4-isopropoxyphthalonitrile (7) reacted with $0.15 \mathrm{~g}(1.66 \mathrm{mmol})$ of cuprous cyanide in $2 \mathrm{~mL}$ of DMF at $145^{\circ} \mathrm{C}$ for $20 \mathrm{~h}$ to give, after the standard work-up described above, $0.080 \mathrm{~g}$ of 2,9,16,23-tetraiso- 
propoxyphthalocyaninatocopper $(13 b)$ in $34 \%$ yicld as a dark bluc solid; ir $\left(\mathrm{cm}^{-1}\right): 1610(\mathrm{C}=\mathrm{C}), 1245,1100,1055,750 ; \mathrm{ms}, \mathrm{m} / \mathrm{z}: 809$ (100), $808\left(\mathrm{M}^{+}, 55\right), 807(67), 765(36), 724$ (16). Anal, calcd. for $\mathrm{C}_{44} \mathrm{H}_{40} \mathrm{~N}_{8} \mathrm{O}_{4} \mathrm{Cu}: \mathrm{C} 65.37, \mathrm{H} 4.99, \mathrm{~N}$ 13.86, Cu 7.86; found: C 65.00,

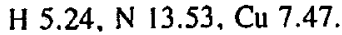

In a typical procedure using Method C (21), $0.38 \mathrm{~g}(2.0 \mathrm{mmol})$ of 7 reacted with $0.14 \mathrm{~g}$ ( $1.0 \mathrm{mmol})$ of cupric chloride and $0.62 \mathrm{~g} \mathrm{(5}$ $\mathrm{mmol}$ ) of diazabicyclononane (DBN) in $10 \mathrm{~mL}$ of absolute alcohol at reflux temperatures for $24 \mathrm{~h}$ to give, after the standard work-up, 0.20 $\mathrm{g}$ of $13 \mathrm{~b}$ in $49 \%$ yield. Although Method $C$ gave $13 \mathrm{~b}$ in higher yields than Method B, repetitive flash chromatography of the reaction product was necessary to remove some fluorescent impurities and hence, in general, Method B or Method D (see below) is preferred.

\section{2,9,16,23-Tetraisopropoxyphthalocyaninatocolsalt(li) $(13 \mathrm{c})$}

Using Methods B and C, 7 was readily converted (Table 1) into 2,9,16,23-tetraisopropoxyphthalocyaninatocobalt(II) $(\mathbf{1 3} c)$, isolated as a shining dark blue solid; ir $\left(\mathrm{cm}^{-1}\right): 1615(\mathrm{C}=\mathrm{C}), 1245,1100$, 1060, 755; ms, m/z: $804\left(\mathrm{M}^{+}, 100\right), 803$ (49), 762 (19). Anal. calcd. for $\mathrm{C}_{44} \mathrm{H}_{40} \mathrm{~N}_{8} \mathrm{O}_{4} \mathrm{Co}$ : $\mathrm{C} 65.75, \mathrm{H} \mathrm{5.02}, \mathrm{N} \mathrm{13.94,} \mathrm{Co} 7.33$; found: C 65.73, H 4.99, N 13.63, Co 7.49.

\section{2,9,16,23-Tetraisopropoxyphthalocyaninatozinc (13d)}

Using methods B and C. 7 was converted (Table 1) into 2,9,16,23tetraisopropoxyphthalocyaninatozinc $(\mathbf{1 3} d)$, isolated as a shining, dark blue solid; ir $\left(\mathrm{cm}^{-1}\right)$ : $1610(\mathrm{C}=\mathrm{C}), 1240,1100.1050,750 ;{ }^{13} \mathrm{C}$ $\mathrm{nmr}\left(\mathrm{CD}_{2} \mathrm{Cl}_{2}, 400 \mathrm{MHz}\right) \delta: 159.3$ (aromatic $\left.\mathrm{C}-\mathrm{O}\right), 125.4,121.7$, 109.4. $71.5\left(\mathrm{CH}_{2}-\mathrm{O}\right), 70.6\left(\mathrm{CH}_{2}-\mathrm{O}\right), 22.7\left(\mathrm{CH}_{3}\right), 21.8\left(\mathrm{CH}_{3}\right)$; $\mathrm{ms}_{2} \mathrm{~m} / \mathrm{z}: 813(64), 812(79), 81 \mathrm{l}(96), 810\left(\mathrm{M}^{+}, 95\right), 809(100), 808$ (70), 767 (31). Anal. calcd. for $\mathrm{C}_{44} \mathrm{H}_{413} \mathrm{~N}_{8} \mathrm{O}_{4} \mathrm{Zn}: \mathrm{C} 65.23, \mathrm{H} 4.98$, $\mathrm{N}$ 13.83, Zn 8.07; found: C 65.41, H 5.00, N 13.76, Zn 7.76.

Metal insertion reactions on metal-free phthalocyanines. 2,9,16,23Tetraisobutoxyphthalocyaninatocopper (14b) (Method D in toluene)

To a solution of $100 \mathrm{mg}(0.12 \mathrm{mmol})$ of 2,9,16,23-tetraisobutoxyphthalocyanine $(14 a)$ in $10 \mathrm{~mL}$ of toluene was added $150 \mathrm{mg}(0.83$ mmol) of cupric acetate. The solution was stirred at $100^{\circ} \mathrm{C}$ under an argon atmosphere for $3 \mathrm{~h}$. The crude reaction mixture was applied to 3 tlc preparative plates, and eluted 3 times with 2-methoxyethanol toluene $(1: 100)$ to give a dark green band which was extracted with toluene in a Soxhlet extractor. Further purification by flash chromatography using 2-methoxyethanol - toluene $(1: 20)$ gave in $74 \%$ yield $80 \mathrm{mg}$ of 2,9,16,23-tetraisobutoxyphthalocyaninatocopper $(14 b)$ as a dark blue, shining solid; ir $\left(\mathrm{cm}^{-1}\right)$ : $1620(\mathrm{C}=\mathrm{C}), 1250$, I $105,1065,755 ; \mathrm{ms}, \mathrm{m} / \mathrm{z}$ : 867 (28), $866\left(\mathrm{M}^{+}, 56\right) .865$ (71), 864 (100), 863 (59), 808 (25). Anal. ealcd. for $\mathrm{C}_{45} \mathrm{H}_{48} \mathrm{~N}_{8} \mathrm{O}_{4} \mathrm{Cu}: \mathrm{C} 66.53$, H 5.60. N 12.77, Cu 7.02; found: C 66.68, H 5.61, N 12.96, Cu 7.35.

\section{2,9,16,23-Tetrameopentoxyphthalocyaninatocopper (15b) and 2,9,16,23-tetraneopentoxyphthalocyaninatocobalt(li) $(15 \mathrm{c})$ \\ (Method D. in DMF and 2-N,N-dimethylaminoethanol)}

To a solution of $41 \mathrm{mg}(0.048 \mathrm{mmol})$ of $15 a$ in $3 \mathrm{~mL}$ of a $1: 2$ mixture of dry DMF and 2- $N, N$-dimethylaminoethanol was added 10 $\mathrm{mg}(0.074 \mathrm{mmol})$ of anhydrous cupric chloride. The mixture was heated for $1 \mathrm{~h}$ under an argon atmosphere using an oil bath heated to $110^{\circ} \mathrm{C}$. The mixture was cooled to room temperature and directly subjected to flash chromatography using freshly distilled toluene as the eluting solvent to give in $94 \%$ yield (Table 1) $41 \mathrm{mg}$ of 2,9,16,23-tetraneopentoxyphthalocyaninatocopper $(15 b)$ as a dark blue, shining solid; ir $\left(\mathrm{cm}^{-1}\right): 1615(\mathrm{C}=\mathrm{C}), 1240,1100,1060,745$; ms, $m / z$ : 922 (78), $921\left(\mathrm{M}^{+}, 81\right), 920(100), 864$ (4), 850 (9). Anal. calcd. for $\mathrm{C}_{52} \mathrm{H}_{56} \mathrm{~N}_{8} \mathrm{O}_{4} \mathrm{Cu}: \mathrm{C} 67.84, \mathrm{H} 6.13, \mathrm{~N} \mathrm{12.17}$, Cu 6.90; found: C 68.10, H 6.24, N 11.89, Cu 6.97.

Similarly, $33 \mathrm{mg}$ of $15 \mathrm{a}$ gave in $94 \%$ yield (Table 1) $33 \mathrm{mg}$ of 2,9.16,23-tetraneopentoxyphthalocyaninocobalt(II) (15c) as a dark blue, shining solid; ir $\left(\mathrm{cm}^{-1}\right)$ : $1615(\mathrm{C}=\mathrm{C}), 1240,1100,1065,750$; $\mathrm{ms}, \mathrm{m} / \mathrm{z}$ : $916\left(\mathrm{M}^{+}, 100\right), 915(47), 859(7), 846(19)$. Anal. calcd. for $\mathrm{C}_{52} \mathrm{H}_{56} \mathrm{~N}_{\mathrm{x}} \mathrm{O}_{4} \mathrm{Co}$ : C 68.18, H 6.16, N 12.23, Co 6.43; found: C 68.22, H 6.14, N 12.07, Co 6.94.

Compounds $15 b$ and $15 c$ were also prepared directly from 9 by the methods of Pawlowski and Hanack (20) (Method B, Table 1).

\section{2,9,16,23-tetraneopentoxypthalocyaminatozinc (15d)}

Using a modification of the procedure of Pawloski and Hanack (20) (Method B), $394 \mathrm{mg}$ (1.84 mmol) of 4-neopentoxyphthalonitrile (9) was suspended in $2 \mathrm{~mL}$ of dry DMF. Zinc acetate $(1.04 \mathrm{~g}, 5.66 \mathrm{mmol})$ was added and the mixture heated using an oil bath at $155^{\circ} \mathrm{C}$ under argon. The clear reaction mixture turned yellow after $\mathrm{l} h$ and dark green after an additional I h. After heating for $20 \mathrm{~h}$ at $155^{\circ} \mathrm{C}$, the mixture was cooled to room temperature, diluted with water, filtered, and washed thoroughly with water. The crude product was purified by flash chromatography using petroleum ether - ether $(6: 1)$ as the eluting solvent to give in $27 \%$ yield (Table 1) $114 \mathrm{mg}$ of $2,9,16,23$ tetraneopentoxyphthalocyaninatozinc $(15 d)$ as a dark blue, shining solid; ir $\left(\mathrm{cm}^{-1}\right): 1610(\mathrm{C}=\mathrm{C}), 1240,1100,1060,750$; $\mathrm{H} \mathrm{nmr}$ $\left(\mathrm{CD}_{2} \mathrm{Cl}_{2}, 250 \mathrm{MHz}\right) \delta: 7.7-6.1$ (m, $12 \mathrm{H}$, aromatic), 3.5 (s. $8 \mathrm{H}$, $\left.\mathrm{CH}_{2} \mathrm{O}\right), 1.3\left(\mathrm{~s}, 36 \mathrm{H}, \mathrm{CH}_{3}\right) ;{ }^{13} \mathrm{C} \mathrm{nmr}\left(\mathrm{CD}_{2} \mathrm{Cl}_{2}, 250 \mathrm{MHz}\right) \delta: 160.1$ (aromatic $\mathrm{C}-\mathrm{O}), 149.5,121.7,121.3,116.9,116.6,104.2,103.9$, $78.2\left(\mathrm{CH}_{2} \mathrm{O}\right), 78.1\left(\mathrm{CH}_{2} \mathrm{O}\right), 32.2\left(\mathrm{CH}_{3} \mathrm{C}\right) .27 .1\left(\mathrm{CH}_{3} \mathrm{C}\right), 26.8$ $\left(\mathrm{CH}_{3} \mathrm{C}\right), 26.5\left(\mathrm{CH}_{3} \mathrm{C}\right) ; \mathrm{ms}, \mathrm{m} / \mathrm{z}$ : 925 (52), 924 (84), 923 (91), 922 $\left(\mathrm{M}^{+}, 97\right), 921$ (100), 868 (2), 853 (40). Anal. calcd. for $\mathrm{C}_{52} \mathrm{H}_{5 \times} \mathrm{N}_{\mathrm{x}} \mathrm{O}_{4} \mathrm{Zn:} \mathrm{C} 67.71, \mathrm{H} 6.12, \mathrm{~N}$ 12.15. Zn 7.07; found: $\mathrm{C} 67.80$, H 6.39. N 11.85, Zn 6.94.

\section{2-Methyl-2-trityloxymethyl-1,3-propanediol (17)}

To a solution of 1,1,1-tris(hydroxymethyl)ethane (16) $(6.48 \mathrm{~g}$, $54.00 \mathrm{mmol}$ ) in $15 \mathrm{~mL}$ of dry pyridinc, triphenylmethyl chloride ( 2.60 $\mathrm{g}, 9.32 \mathrm{mmol}$ ) was added and the mixture was stirred for $22 \mathrm{~h}$ at room temperature under exclusion of moisture $\left(\mathrm{CaCl}_{2}\right.$ drying tube). The mixture was then poured into $180 \mathrm{~mL}$ of icc-water and extracted 4 times with ether. The combined ether extracts were washed six times with water, dried over anhydrous $\mathrm{MgSO}_{4}$, and cvaporated to give a viscous oil which was dried under high vacuum for $4 \mathrm{~h}$. The crude product was purified by column chromatography on silica gel using a mixture of chloroform-hexane (3:!) as the eluting solvent. Evaporation of the solvent yielded a product which was recrystallized from a mixture of ether-hexane to give in $68 \%$ yicld $2.18 \mathrm{~g}$ of white crystals, $m p 127-128^{\circ} \mathrm{C}$; ir $\left(\mathrm{cm}^{-1}\right): 3360(\mathrm{OH}), 1600(\mathrm{C}=\mathrm{C}), 1500$, 1495, 1050, 770, 710, 705; 'H nmr $\left(\mathrm{CDCl}_{3}, 60 \mathrm{MHz}\right) \delta: 7.6-7.2(\mathrm{~m}$, $15 \mathrm{H}$, aromatic), $3.65\left(\mathrm{~d}, 4 \mathrm{H}, \mathrm{CH}_{2} \mathrm{O}, J=6 \mathrm{~Hz}\right), 3.2\left(\mathrm{~s}, 2 \mathrm{H}, \mathrm{CH}_{2} \mathrm{O}\right)$, $2.4(\mathrm{t}, 2 \mathrm{H}, \mathrm{OH}, J=6 \mathrm{~Hz}), 0.8\left(\mathrm{~s}, 3 \mathrm{H}, \mathrm{CH}_{3}\right) ;{ }^{13} \mathrm{C}$ nmr $\left(\mathrm{CDCl}_{3}, 400\right.$ $\mathrm{MHz}$ ) $8: 143.7$ (aromatic C-1'), 128.6 and 127.9 (aromatic C-2', C-6', C-3', C-5'), 127.1 (aromatic C-4'), $86.7(\mathrm{PhC}), 67.8$ $\left(\mathrm{CH}_{2} \mathrm{OC}\right), 67.0\left(\mathrm{CH}_{2} \mathrm{OH}\right), 41.1\left(\mathrm{CCH}_{2}\right), 17.3\left(\mathrm{CH}_{3}\right) ; \mathrm{ms}, \mathrm{m} / \mathrm{z}: 362$ $\left(\mathrm{M}^{+}, 3\right), 285(20), 259(50), 239(100), 183(80), 105(75), 77$ (23). Anal. calcd. for $\mathrm{C}_{24} \mathrm{H}_{26} \mathrm{O}_{3}: \mathrm{C} 79.53, \mathrm{H} 7.23$; found: $\mathrm{C} 79.58, \mathrm{H} 7.19$.

\section{1,3-Bis(3',4'-dicyanophenoxy)-2-methyl-2-trityloxymethylpropane \\ (20) 1,3-bis(3',4'-dicyanophenoxy)-2,2-dimethylpropane (21), \\ and 1,3-bis( $3^{\prime}, 4^{\prime}$-dicyanophenyl)-2-ethyl-2-methylpropane (22)}

A solution of $1.09 \mathrm{~g}(3.01 \mathrm{mmol})$ of $17,1.07 \mathrm{~g}(6.18 \mathrm{mmol})$ of 1 , and $1.75 \mathrm{~g}(12.68 \mathrm{mmol})$ of anhydrous potassium carbonate was heated at $65^{\circ} \mathrm{C}$ in $7 \mathrm{~mL}$ of dry DMSO by the method of Keller et al. (16). The reaction mixture was filtered and washed with methylene chloride $\left(\mathrm{CH}_{2} \mathrm{Cl}_{2}\right)$. The filtrate was diluted with $\mathrm{CH}_{2} \mathrm{Cl}_{2}$ and washed thoroughly 6 times with water and finally with saturated sodium chloride. After drying over anhydrous magnesium sulfate $\left(\mathrm{MgSO}_{4}\right)$, the solvent was evaporated to give $1.77 \mathrm{~g}$ of a light brown solid. The crude product was purified by flash chromatography using chloroformhexane $(3 ; 1)$ as the eluting solvent. Evaporation of the solvent yielded an oil which was dissolved in warm methanol and rapidly cooled to $-35^{\circ} \mathrm{C}$ (but not lower) to give in $56 \%$ yield $1.02 \mathrm{~g}$ of $1,3-\mathrm{bis}\left(3^{\prime}, 4^{\prime}-\right.$ dicyanophenyl)-2-methyl-2-trityloxymethylpropane $(20)$ as light yellow crystals, $\mathrm{mp} 89-92^{\circ} \mathrm{C}$; ir $\left(\mathrm{cm}^{-1}\right): 2240(\mathrm{CN}), 1600(\mathrm{C}=\mathrm{C})$, 1495, 1255, 1090, 1030, 710, 700; ' $\mathrm{H} \mathrm{nmr}\left(\mathrm{CDCl}_{3}, 60 \mathrm{MHz}\right) \delta$ : $7.80-7.05(\mathrm{~m}, 21 \mathrm{H}$, aromatic $), 4.03\left(\mathrm{~s}, 4 \mathrm{H}, \mathrm{CH} \mathrm{H}_{2} \mathrm{O}\right) 3.30(\mathrm{~s}, 2 \mathrm{H}$, $\left.\mathrm{CH}_{2} \mathrm{O}\right), 1.30\left(\mathrm{~s}, 3 \mathrm{H}, \mathrm{CH}_{3}\right) ; \mathrm{ms}, \mathrm{m} / \mathrm{z}: 614\left(\mathrm{M}^{+}, 18\right), 537(20), 283$ (10), $243(65), 240(100), 183(48), 144(19), 105(58)$. Anal. calcd.

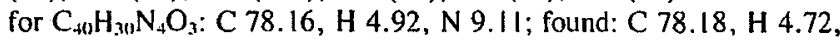
N 8.92. 
Similarly, a solution of $1.04 \mathrm{~g}$ (10.0 mmol) of 2,2-dimethyl-1,3propanediol $(18), 3.81 \mathrm{~g}(22 \mathrm{mmol})$ of 1 , and $6.7 \mathrm{~g}(48.6 \mathrm{mmol})$ of anhydrous $\mathrm{K}_{2} \mathrm{CO}_{3}$ in $10 \mathrm{~mL}$ of dry DMSO gave a crude reaction product. The reaction mixture was filtered and washed with ethyl acetate. The filtrate was diluted with ethyl acetate, thoroughly washed with water until the aqueous layer was clear, and finally washed with a saturated sodium chloride solution. After drying over anhydrous $\mathrm{MgSO}_{4}$, the solvent was evaporated to give a dark brown solid. The crude product was purified by column chromatography on silica gel using benzene-acetonitrile $(9: 1)$ as the eluting solvent. Evaporation of the solvent and recrystallization of the residue from acctonitrilewater gave $1.36 \mathrm{~g}(38 \%)$ of 1,3-bis( $3^{\prime}, 4^{\prime}$-dicyanophenoxy)-2,2-dimethylpropane (21) as creamy crystals. mp $168-169^{\circ} \mathrm{C}$; ir $\left(\mathrm{cm}^{-1}\right)$ : $2240(\mathrm{CN}), 1600(\mathrm{C}=\mathrm{C}), 1260,1100,1040,845$; ' $\mathrm{H}$ nmr (acetone$\left.d_{\text {t. }} 60 \mathrm{MHz}\right) 8: 8.10-7.42\left(\mathrm{~m}, 6 \mathrm{H}\right.$, aromatic), 4.27 (s, 4H, $\left.\mathrm{CH}_{2} \mathrm{OC}\right)$, 1.27 (s, 6H, CH 3$) ; \mathrm{ms}, \mathrm{m} / z: 356\left(\mathrm{M}^{+}, 11\right) .213(30), 171(88), 127$ (43). Alral caled. for $\mathrm{C}_{21} \mathrm{H}_{16} \mathrm{~N}_{4} \mathrm{O}_{2}$ : C 70.78, H 4.52, N 15.72; found: C 70.74, H 4.37, N 15.43.

In a manner similar to that described above for the preparation of $21,1.60 \mathrm{~g}$ of 2-ethyl-2-methyl-1,3-propanediol (19) yielded a crude reaction product. Thin-layer chromatography of this product using benzene-acetonitrile $(9: 1)$ as eluant exhibited the presence of a minor amount of 4-hydroxyphthalonitrile (5). Thus, the ethyl acetate filtrate was washed several times with water, followed by $0.5 \mathrm{M}$ cold $\mathrm{NaOH}$, water, and finally saturated $\mathrm{NaCl}$ solution. The ethyl acetate solution yielded upon the normal work-up a dark brown solid. The aqueous layer was acidified with dilute $\mathrm{HCl}$ and the organic material was extracted into ethyl acetate. The ethyl acctate was dried over anhydrous $\mathrm{MgSO}_{4}$, filtered, and evaporated to give $560 \mathrm{mg}$ of 5 (18) which was not further purified. Purification of the dark brown solid, obtained from the original ethyl acetate extract above, yielded, upon recrystallization from ethyl acetate - hexanes, $1.84 \mathrm{~g}(37 \%)$ of 1,3-bis$\left(3^{\prime}, 4^{\prime}\right.$-dicyanophenoxy)-2-ethyl-2-methylpropane $(22)$ as creamy crystals, mp $157-158^{\circ} \mathrm{C}$; ir $\left(\mathrm{cm}^{-1}\right): 2240(\mathrm{CN}), 1600(\mathrm{C}=\mathrm{C}), 1260$, $1095,1025,845 ;{ }^{\prime} \mathrm{H} \mathrm{nmr}\left(\mathrm{CDCl}_{3}, 60 \mathrm{MHz}\right) \delta: 7.87-7.18(\mathrm{~m}, 6 \mathrm{H}$, aromatic), $4.03\left(\mathrm{~s}, 4 \mathrm{H}, \mathrm{CH}_{2} \mathrm{O}\right), 1.62\left(\mathrm{q}, 2 \mathrm{H}, \mathrm{CH}_{2} \mathrm{C}, J=7 \mathrm{~Hz}\right), 1.18$ (s, $\left.3 \mathrm{H}, \mathrm{CH}_{3} \mathrm{C}\right), \mathrm{I} . \mathrm{lO}\left(\mathrm{t}, 3 \mathrm{H}, \mathrm{CH}_{3} \mathrm{CH}_{2}, J=7 \mathrm{~Hz}\right) ; \mathrm{ms}, \mathrm{m} / \mathrm{z}: 370\left(\mathrm{M}^{+}\right.$, 23), 227 (46), $185(60), 171$ (65), 127 (52). Anal. caled. for $\mathrm{C}_{22} \mathrm{H}_{18} \mathrm{~N}_{4} \mathrm{O}_{2}: \mathrm{C} 71.34, \mathrm{H} 4.90, \mathrm{~N} 15.12$; found: $\mathrm{C} 71.30, \mathrm{H}$ 5.03, N 15.09 .

\section{Preparation of the bis-1,3-diiminoisoindolines 23 and 24}

Compounds 23 and 24 were prepared from 21 and 22 respectively as described above for 10-12 with one minor exception. As 21 and 22 were only slightly soluble in methanol at room temperature, these compounds werc dissolved in a solution of sodium methoxide in methanol at $65^{\circ} \mathrm{C}$ and ammonia was bubbled into this solution for $I \mathrm{~h}$ at $65^{\circ} \mathrm{C}$ and for $3 \mathrm{~h}$ under reflux conditions.

\section{1,3-Bis-2'-(9', 16',23'-triisopropoxyphthalocyaninoxycopper $)-2$ - methyl-2-trityloxymethylpropane (25)}

A mixture of $0.14 \mathrm{~g}(0.23 \mathrm{mmol})$ of $20,1.0 \mathrm{~g}(5.4 \mathrm{mmol})$ of 7 , and $1.54 \mathrm{~g}$ ( $17.23 \mathrm{mmol}$ ) of cuprous cyanide was heated at $130^{\circ} \mathrm{C}$ (oil bath) in $7.5 \mathrm{~mL}$ of dry DMF for $20 \mathrm{~h}$ under argon atmosphere (Method B) (20). After dilution with ammonia, the product was filtered and washed with water. The dark blue-green residue was dissolved in toluene and chromatographed under argon using the flash chromatography technique. Elution with 2-methoxyethanol - toluene $(1: 40)$ gave, upon solvent evaporation, $340 \mathrm{mg}$ of $2,9,16,23$-tetraisopropoxyphthalocyaninatocopper $(13 b)$ in $31 \%$ yield. Elution with 2-methoxyethanol - toluene $(1: 4)$ gave a slightly impure product. Thin-layer chromatography of this product exhibited a major blue spot and slightly faster moving green impurity (2-methoxyethanol toluene, $\mathrm{I}: 4$ as eluant). Further purification by flash chromatography using a small diameter column $(1 \mathrm{~cm})$ gave in $1 \%$ yield $6 \mathrm{mg}$ of

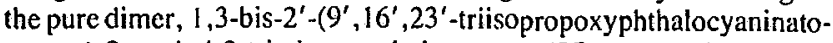
copper)-2-methyl-2-trityloxymethylpropane (25) as a dark blue, shining solid; ir $\left(\mathrm{cm}^{-1}: 1615(\mathrm{C}=\mathrm{C}), 1250,1120,1105,1060,755\right.$; $\mathrm{ms}, \mathrm{m} / \mathrm{z}: 1859.5\left(\mathrm{M}^{+}\right), 1816\left(M^{+}-43\right)$. Anal. calcd. for
$\mathrm{C}_{1 k_{6}} \mathrm{H}_{9,} \mathrm{~N}_{16} \mathrm{O}_{1} \mathrm{Cu}_{2}: \mathrm{C} 68.48, \mathrm{H} 4.88, \mathrm{~N} 12.05$; found: $\mathrm{C} 67.85, \mathrm{H} 5.34$, $\mathrm{N} 12.53$.

l,3-Bis-2'-(9', I6',23'-trineopentexyphthalocyaninoxy)-2,2-dimethylpropane (26a) and I.3-bis-2' $-\left(9^{\prime}, 16^{\prime}, 23^{\prime}\right.$-trineopentoxyphthalocyaninoxy)-2-ethyl-2-methylpropane (27a)

The two crude diiminoisoindolines 12 and 23 obtained from $4.2 \mathrm{~g}$ (19.6 mmol) of 4-neopentoxyphthalonitrile (9) and $249 \mathrm{mg}(0.7$ $\mathrm{mmol}$ ) of 1,3-bis-( $3^{\prime}, 4^{\prime}$-dicyanophenoxy)-2.2-dimethylpropane (21), respectively, wcre heated at $150^{\circ} \mathrm{C}$ (oil bath) in $30 \mathrm{~mL}$ of $2-N, N$-dimethylaminoethanol for $23 \mathrm{~h}$ under an argon atmosphere. The mixture gradually changed colour from yellow to dark blue. After cooling to room temperature, the mixture was diluted with water and the blue coloured residue was filtered and washed thoroughly with water until the filtrate was colourless. The crude product was purified in two separate batches by flash chromatography using a $5 \mathrm{~cm}$ wide column packed with silica gel $9 \mathrm{~cm}$ high. The dark blue-green product was preadsorbed on silica and eluted with $1500 \mathrm{~mL}$ of freshly distilled toluene to give $1.92 \mathrm{~g}$ of the monomeric $2,9,16,23$-tetraneopentoxyphthalocyanine (15a) in $46 \%$ yield. Further elution with 2-methoxyethanol - toluene in ratios of 1:40 and 1:10 yielded, after solvent cvaporation, $340 \mathrm{mg}$ of a purified product, containing traces of monomer $15 a$ and some green material (fluorescent under uv) which moved closcly behind the desired product when examined by tle (2-methoxyethanol - tolucne, 1:40 as eluting solvent). Flash chromatography of this purificd material on a smalier column $3 \mathrm{~cm}$ wide removed, on elution with toluene and 2-methoxycthanol - toluene $(1: 100)$, all traces of monomer 15a. Further clution with 2-methoxyethanol - toluene $(1: 20)$ yielded some fractions of a very pure, dark blue product. Other fractions were still contaminated with the green material. Purification of these fractions was achieved using preparative tlc and 2-methoxyethanol - toluene $(1: 20)$ as eluting solvent. Finally, the product was purified by flash chromatography as above to give in $17 \%$ yield $195 \mathrm{mg}$ of 1,3 -bis- $2^{\prime} \cdot\left(9^{\prime}, 16^{\prime}, 23^{\prime}\right.$-trineopentoxyphthalocyaninoxy)-2,2-dimethylpropane (26a) as a very pure, dark blue, shining solid; ir $\left(\mathrm{cm}^{-1}\right)$ : $3300(\mathrm{NH}), 1615(\mathrm{C}=\mathrm{C}), 1240,1100$, 1055, $1020(\mathrm{NH}), 750 ;{ }^{\prime} \mathrm{H} \mathrm{nmr}\left(\mathrm{CD}_{2} \mathrm{Cl}_{2}, 400 \mathrm{MHz}\right) 8: 8.21-7.12$ (br), 4.05-3.65 (br), $1.42(\mathrm{br}),-6.12(\mathrm{br}) ;{ }^{13} \mathrm{C} \mathrm{nmr}\left(\mathrm{CD}_{2} \mathrm{Cl}_{2}, 400\right.$ $\mathrm{MHz})$ 8: $32.35\left(\mathrm{CH}_{3} \mathrm{C}\right), 27.20\left(\mathrm{CH}_{3} \mathrm{C}\right) ; \mathrm{ms}, m / z: 1645(100), 1644$

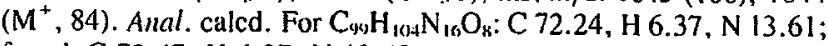
found: C 72.47, H 6.27, N 13.49.

Similarly, the two crude isoindolines 12 and 24 obtained from $5.6 \mathrm{~g}(26.2 \mathrm{mmol})$ of 9 and $0.4 \mathrm{~g}(1.08 \mathrm{mmol})$ of 22 , respectively, yielded $1.72 \mathrm{~g}$ of $15 \mathrm{a}$ in $31 \%$ yield and $184 \mathrm{mg}$ in $10 \%$ yield of $1,3-$

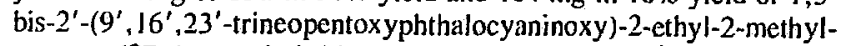
propane (27a) as a dark blue, shining solid; ir $\left(\mathrm{cm}^{-1}\right): 3310(\mathrm{NH})$, $1618(\mathrm{C}=\mathrm{C}), 1240,1100,1058,1020(\mathrm{NH}), 750 ;{ }^{1} \mathrm{H} \mathrm{nmr}\left(\mathrm{CDCl}_{3}\right.$, $400 \mathrm{MHz}$ ) 8: $9.4-6.8(\mathrm{br}), 4.2-3.6(\mathrm{br}), 1.8-0.8(\mathrm{br}),-5.8-$ (-6.4) (br); ${ }^{13} \mathrm{C} \mathrm{nmr}\left(\mathrm{CD}_{2} \mathrm{Cl}_{2}, 400 \mathrm{MHz}\right) \delta: 78.6\left(\mathrm{CH}_{2} \mathrm{O}\right), 32.4$ $\left(\mathrm{CCH}_{3}\right), 30.1\left(\mathrm{CCH}_{2}\right), 27.2\left(\mathrm{CH}_{3} \mathrm{C}\right), 26.6\left(\mathrm{CCH}_{2} \mathrm{CH}_{3}\right) ; \mathrm{ms}, \mathrm{m} / \mathrm{z}$ : $1662(100), 1660\left(\mathrm{M}^{+}, 41\right), 1658$ (30). Anal. calcd. for

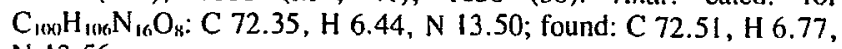
N 13.56.

\section{1,3-Bis-2'- $\left(9^{\prime}, 16^{\prime}, 23^{\prime}\right.$-trineopentoxyphthalocyaninoxycopper $)-2,2$ -}

dimethylpropane (26b), l,3-bis-2'-19',16',23'-trineopentoxyphthalocyaninoxycobaltll)-2,2-dimethylpropane (26c), and 1,3bis-2'-(9',16',23'-trineopentoxyphthalocyaninorycobaltll)-2ethyl-2-methylpropane (27b)

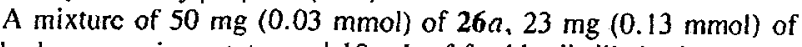
anhydrous cupric acetate, and $10 \mathrm{~mL}$ of freshly distilled toluene was heated at $100^{\circ} \mathrm{C}$ for $17 \mathrm{~h}$ under an argon atmosphere. The solution was cooled and purified by flash chromatography (26) by direct application of the crude reaction product to the column. Elution with 2-methoxyethanol - toluene $(7: 200)$ gave. after solvent evaporation, $29 \mathrm{mg}$ ( $54 \%$ yield) of a dark blue, shining product which was washed with anhydrous ether to remove very minor fluorescent impuritics (detected by thc) leaving $28 \mathrm{mg}$ of very pure I,3-bis-2'-(9,16,23-trineopentoxyphthalocyaninoxycopper)-2,2-dimethylpropane (26b); ir 
$\left(\mathrm{cm}^{-1}\right): 1615(\mathrm{C}=\mathrm{C}), 1240,1100,1060,750 ; \mathrm{ms}, \mathrm{m} / \mathrm{s}: 1772,1771$, 1770. 1769, $1768\left(\mathrm{M}^{+}\right), 1767$. Anal. calcd. for $\mathrm{C}_{(4)} \mathrm{H}_{1(6)} \mathrm{N}_{16} \mathrm{O}_{4} \mathrm{Cu}_{2}: \mathrm{C}$ 67.22, H 5.70, N 12.67, Cu 7.18; found: C 67.4I, H 5.52, N 12.40, $\mathrm{Cu} 6.83$.

Similarly, $50 \mathrm{mg}(0.03 \mathrm{mmol})$ of $26 \mathrm{a}$ and $105 \mathrm{mg}(0.81 \mathrm{mmol})$ of anhydrous cobaltic chloride in $15 \mathrm{~mL}$ of a $1: 2$ mixture of 2-methoxyethanol - toluene was heated at $100^{\circ} \mathrm{C}$ for $20 \mathrm{~h}$ to give, after purification as above, $32 \mathrm{mg}$ ( $60 \%$ yield) of 1,3-bis-2'. $\left(9^{\prime}, 16^{\prime}, 23^{\prime}\right.$-trineopentoxyphthalocyaninoxycobaltli)-2,2-dimethylpropane (26c) as a dark blue, shining solid: ir $\left(\mathrm{cm}^{-1}\right): 1615(\mathrm{C}=\mathrm{C})$, 1240, 1100, 1068, 755; ms, $\mathrm{m} / \mathrm{z}: 1761$ (61), $1760\left(\mathrm{M}^{+}, 100\right), 1759$. Anal. calcd. for $\mathrm{C}_{y y} \mathrm{H}_{1000} \mathrm{~N}_{10} \mathrm{O}_{8} \mathrm{Co}_{2}: \mathrm{C} 67.57, \mathrm{H} 5.73, \mathrm{~N} 12.73$, Co 6.70; found: C 67.92, H 5.88, N 12.84, Co 6.25.

Similarly, $70 \mathrm{mg}(0.04 \mathrm{mmol})$ of 27 a and $57 \mathrm{mg}(0.44 \mathrm{mmol})$ of anhydrous cobaltic chloride in $10 \mathrm{~mL}$ of a $3: 7$ mixture of 2-methoxyethanol - toluene were heated at $110^{\circ} \mathrm{C}$ for $24 \mathrm{~h}$ under an argon atmosphere. Purification as above gave $55 \mathrm{mg}$ ( $74 \%$ yicld) of pure 1,3-bis-2'-(9', 16',23'-trineopentoxyphthalocyaninatocobalt1I)-2-ethyl2-mcthylpropanc $(27 \mathrm{~b})$ as a dark bluc, shining solid; ir $\left(\mathrm{cm}^{-1}\right): 1620$ $(\mathrm{C}=\mathrm{C}), 1245,1100,1068,758 ; \mathrm{ms}, \mathrm{m} / \mathrm{z}: 1774\left(\mathrm{M}^{+}, 100\right)$. Anal. calcd. for $\mathrm{C}_{1(16)} \mathrm{H}_{102} \mathrm{~N}_{16} \mathrm{O}_{k} \mathrm{Co}_{2}$ : C 67.71, H 5.80, $\mathrm{N}$ 12.63, Co 6.64; found: C 68.14, H 6.21, N 12.61, Co 6.64.

\section{Acknowledgements}

We are grateful to the Natural Sciences and Engineering Research Council of Canada for financial support of this research. This work was also partially funded by the Office of Naval Research (Washington) and by the Midwest Center for Mass Spectrometry, a National Science Foundation Regional Instrumentation Facility (Grant No. CHE 8211164). We thank Dr. Jack Martin Miller of Brock University for providing the mass spectra of the mononuclear metallophthalocyanines, $15 b-d$.

1. R. JASINSK1. Nature, 201, 1212 (1964); J. Electrochem. Soc. 112, 526 (1965).

2. P. Sayer. M. Gouterman, and C. R. Connell. Acc. Chem. Res. 15, 73 (1982).

3. M. R. TARASEvitCh and Radyshikina. Usp. Khim. 49, 1498 (1980); Russ. Chem. Rev. 49, 718 (1980).

4. F. VAN DEN BRINK, E. BARENDRECht, and W. VisSChER. Recl. Trav. Chim. Pays-Bas, 99, 253 (1980).

5. J. P. Collman. Acc. Chem. Res. 10, 265 (1977).

6. F. P. SCHWARZ, M. Gouterman, Z. Muluiani, and D. H. Dol.phin. Bioinorg. Chem. 2, I (1972); J. HIOM, J. B. PAINE III, V. ZAPF, and D. DolPhiN. Can. J. Chem. 61, 2220 (1983).

7. J. P. Collman, F. C. Anson, S. Bencosme, A. Chong, T. Collins, P. Denisevich, E. EvitT, T. Geiger, J. A. IBers, G. Jameson, Y. Konal, C. Koval, K. Meier, P. OAkley, R. B. Pettman, E. Schmittov, and J. Sessler. In Organic synthesis today and tomorrow. Eclited by B. M. Trost and C. R. Hutchinson. Pergamon, Oxford. 1981.

8. J. P. Collman, F. C. Anson, C. E. Barnes, C. S. Bencosme, T. Geiger, E. R. EvitT, R. P. KRCH, K. MEIER, and R. B.
Petrman. J. Am. Chem. Soc. 105, 2694 (1983).

9. C. K. Chang. J. Am. Chem. Soc. 99, 2819 (1977); N. E. Kagan, D. Mauzerall, and R. B. Merrifield. J. Am. Chem. Soc. 99, 5484 (1977); J. E. BALdwin, M. J. CrossLey, T. Klose, E. A. O’Rear, and M. K. Peters. Tetrahedron, 38 , 27 (1982); I. Tabushi and T. SaSaki. J. Am. Chem. Soc. 105, 2901 (1983).

10. A. B. P. Lever. Adv. Inorg. Chem. Radiochem. 7, 27 (1965).

11. C. C. LezNofF and T. W. HALL. Tetrahedron Lett. 23, 3023 (1982).

12. T. W. Hall, S. Greenberg, C. R. McArthur, B. Khouw, and C. C. Leznoff. Nouv. J. Chim. 6, 653 (1982).

13. R. W. Murray. Acc. Chem. Res. 13, 135 (1980).

14. P. Sayer, M. Gouterman, and C. R. Connell. Acc. Chem. Res. 15, 73 (1982).

I5. W. O. SIEGL. J. Hetereocycl. Chem. 18, 1613 (1981).

16. T. M. KelleR, T. R. Price, and J. R. GRIfFITH. Synthesis, 613 (1980); T. M. Keller and J. R. GRIfFith. U.S. Patent No. 4, 226, 801 (1980).

17. N. P. Marullo and A. W. SnOw. ACS Symposium Serics, 14, 325 (1982).

18. V. A. Ustinov, V. V. Plakhtinskil, G. S. Mironov, and N. S. RyabukhinA. J. Org. Chem. USSR, 15, 1595 (1979); Zh. Org. Khim. 15. 1775 (1979).

19. P. J. Beach, S. J. Grammatica, O. A. Ossanna, and L. WeinBERGER. J. Hcterocycl. Chem. 7, 1403 (1970).

20. G. PAWLowSKI and M. HANACK. Synthesis, 287 (1980).

21. H. Tomada, S. Saito, S. Ogawa, and S. Shiraishi. Chem. Lett. 1277 (1980).

22. M. Hanack, J. Metz, and G. Pawlosk1. Chem. Ber. 115, 2836 (1982).

23. J. S. Bradshaw and Richard H. Hales. J. Org. Chem. 36. 318 (1971); J. S. Bradshaw, E. Y. Chen, R. H. Hales, and J. A. South. J. Org. Chem. 37, 205 I (1972); F. DelClima, G. BigGi, and F. PIETro. J. Chem. Soc. Perkin Trans. 2, 55 (1973).

24. H. Shirai, S. Higaki, K. hanabusa, N. Hojo, and O. HiRaBARU. J. Chem. Soc. Chem. Commun. 751 (1983).

25. J. H. FENDLER. Acc. Chem. Res. 13.7 (1980).

26. W. C. Still, M. Kahn, and A. Mitra. J. Org. Chem. 43, 2923 (1978).

27. M. L. Gross, E. K. Chess, P. A. Lyon, F. W. Crow, S. Evans, and H. TudGe. Int. J. Spectrom. Ion. Phys. 42, 243 (1982).

28. H. F. Shurvell and L. Pinzuti. Can. J. Chem. 44, 125 (1966); M. P. SAMmes. J. Chem. Soc. Perkin Trans. 2, 160 (1972).

29. J. T. ClerC, E. Pretsch, and J. Seibl. Structural analysis of organic compounds. Elsevier, New York. 1981. p. 277

30. G. J. RAY, R. J. KURLAND, and A. K. COLTER. Tetrahedron, 27, 735 (1971); A. J. JONES, C. C. LEZNOFF, and P. I. SVIRSKAYA. Org. Magn. Reson. 18, 236 (1982).

31. C. C. Leznoff, S. Greenberg, S. M. Marcuccio, P. C. MinOR, P. SEYMOUR, A. B. P. LEVER, and K. B. TOMER. Inorg. Chim. Acta, 89, L35 (1984). 